\title{
IMPROVEMENT OF TECHNICAL TRAINING OF FUTURE HANDICRAFT TEACHERS
}

\section{Nataliia Minko ${ }^{1}$}

DOI: https://doi.org/10.30525/978-9934-588-15-0-14

\begin{abstract}
The research objective is a theoretical study of the essence of technical training in higher education institutions and the development of ways for improving technical training of future handicraft teachers. The research subject is the content and the method of forming of competence of future handicraft teachers to provide students with the lessons of fundamentals of technology. In the course of the study, the following research methods were used: theoretical (analysis of philosophical, psychological-pedagogical and methodological literature, thesis papers on the problem of research, materials and publications of the pedagogical and periodical press as well as comparison, systematization, generalization of the obtained information to determine the state of theory and practice of the formation of technical training of the future teacher, formulation of methodological and theoretical bases of the study, taking into account the domestic and foreign experience in specifying the essence and special aspects of technical training of future handicraft teachers); empirical methods: questionnaire, observation, self-assessment, interviews with students, educators, methodological experts in pedagogical practice and school teachers, analysis of performance through which the study of motivation and readiness of future handicraft teachers for learning the fundamentals of technology with students. Based on the analysis of academic literature, the experience of leading pedagogical staff of education institutions of Ukraine, the introduction of a specialized course of study will contribute to the improvement of the quality of technical training of future handicraft teachers, the provision of students with a system of knowledge about the interoperation of manufacture, equipment and handicraft lessons, the acquisition a system of knowledge, skills and expertise when dealing with sewing and culinary techniques.
\end{abstract}

\footnotetext{
${ }^{1}$ Candidate of Pedagogical Sciences,

Senior Lecturer at the Department of General Technical Disciplines and Drawing,

Deputy Dean of Technology Department,

T.H. Shevchenko National University "Chernihiv Collegium”, Ukraine
}

(C) Nataliia Minko 


\section{Introduction}

One of the fundamental factors in the development of world society is its technologisation - the creation of technology and manual training, first, to ensure the efficiency and quality of industrial processes, and then to optimize human efforts and convenience in everyday life. Thus, the technological area becomes an integral part of the everyday life of the modern man and has a key influence on the formation of a new kind of society. Such demands are rendered in close interrelation with education, its technologisation because education always acts as a tool for shaping the culture of a particular nation improving from generation to generation. A teacher has a leading role in that sort of a process.

The research problem is to determine the content of the system of knowledge, skills and expertise in technology in accordance with the programs of handicraft training (technology) and the choice of ways for the development of technical thinking and improvement of the technical training of future handicraft teachers.

In order to develop a holistic system for improvement of the training of future teachers, the following tasks were established:

1. To analyze the system of disciplines providing the formation of technical competence of the future handicraft teacher, to determine interdisciplinary relationships.

2. To develop a training program for specialized technical course.

3. To develop tasks for pedagogical practice in order to enhance the technical training of students.

\section{Analysis of academic disciplines providing technical training of future handicraft teacher}

Technical training of students of higher education institutions of pedagogical focus is provided by a system of technical disciplines and humanities. They are divided into several cycles.

The cycle of humanities and socio-economic training is the basis for the holistic formation of the importance of technology in human life. When studying disciplines of the cycle, it is considered the issues of the formation and development of technology, the importance of technology in human life, the coexistence of technology and a man, dependence of the individual on the development of public goods, the effectiveness of using equipment to save time and cost. 
The cycle of mathematical, natural-scientific training is the basis for the formation of technical training. On the ground of training courses, all calculations of a technical object necessary for the solution of theoretical and practical problems are grounded, the general properties of the matter and its internal phenomena are determined, as well as the general laws governing these phenomena, which are the basis of the operation of any equipment, are found.

The cycle of professional and practical training ensures the formation and consolidation of professional knowledge, skills and expertise. During this period, it is learned the disciplines which are a basis for the study of the course "Technology and Design" in school. It is considered the special-purpose equipment, the features of its use, and the issues of rational and safe use of equipment by a person are studied.

The formation of qualitative technical training of a student takes three stages:

- the acquisition of general theoretical knowledge, practising of simple technical skills;

- the formation of more complex scientific-technical and other knowledge, which is a basis for the development of more complex skills;

- the origin of technical skills and knowledge functioning in the technical terms [3].

The first stage of training is carried out during fresh and sophomore years. It provides more thorough familiarization of students with majors of the technical focus area, consideration of new technical disciplines, shaping of basic skills compared to the school. This stage also motivates academic activities of students.

The period of study is characterized by the familiarization of students with the basics of theory of training, education and development of personality, the essence of the profession of teacher in general and handicraft teacher in particular, acquisition of certain skills and abilities to study student personality, completion of professional orientation, formation and development of professional focus, academic adaptation of students, development and consolidation of professionally important needs, interests, motives [16, p. 23].

The second training stage is aimed at acquiring and specifying basic knowledge of technical and methodical disciplines, forming the readiness 
of the future teacher to carry out the teaching and educational process at handicraft lessons in junior secondary school, adaptation to the requirements and conditions of the teaching and educational process of school, development and improvement of professionally important needs, motives, personality traits, formation of demands for self-education and self-development [16, p. 23].

The third stage covers the fourth and fifth year of study and generates more sophisticated technical and other knowledge which is the foundation for the formation of more complex skills; it is originated technical skills and knowledge functioning in engineering terms.

Analyzing the curriculum for the training of students of the specialty "Secondary Education (Design and Technology)", the author identifies the disciplines that form the core of technical and methodical training of students to study the basics of technology. In the course of activity, it is concluded that a large number of disciplines of technical focus is the framework for the provision of general technical training of the student, however, in the system of training the handicraft teacher, there is a lack of discipline, which is aimed at the formation of a student's unified vision of the study of special-purpose machines with students in school.

According to "Design and technology curriculum for 5-9 grades of institutions of general secondary education" (updated)" approved by the Order of the Ministry of Education and Science of Ukraine dated 07.06.2017 No. 804 [7], the author proposes to introduce a specialized course of study "Fundamentals of modern technology" for quality improvement of the training of future handicraft teachers in the field of special-purpose machines.

The above course "Fundamentals of modern technology" for future handicraft teachers designed to develop a high level of professional knowledge and skills of students to work with modern equipment of garment and food industry as well as the ability to respond quickly to changes in technological activity and to choose the best ways for tasks completion, to lay down a system of generalized methods of work activity to ensure the professional fulfillment of any production targets at related technological processes.

Essential element for the development of the special course "Fundamentals of modern technology" is to determine the role of the course in the training of future handicraft teachers, to formulate its subject matter, 
information content, and to substantiate the sequence of study of the course content scientifically the structuring of which influences the efficiency of the discipline. Consider the position of the special course in the professional training of the future handicraft teacher (table 1).

As reflected by the table 1, the author proposes to study the special course "Fundamentals of modern technology" at the third stage, when there is a development of technical skills and knowledge functioning in engineering terms, systematization of knowledge in engineering and methodical disciplines, completion of the formation of basic professionally important needs, motives, personal qualities, preparation for self-formation of readiness by constant improvement of level of professional readiness during independent activity [16, p. 23].

The study of the special course takes place at the fourth study year because it has a general nature, provides more profound familiarization with modern technology after the acquisition of the principal stage of training based on a particular background:

- students studied the basic disciplines of natural sciences at the first stage of training;

- students considered the basic engineering disciplines the knowledge of which is the ground to study the above special course;

- students could consolidate the gained technical knowledge when have sewing hands-on course;

- concurrent study of the cooking hands-on course makes it possible to acquire and understand new technical knowledge more thoroughly;

- special course shapes new knowledge and skills in the basics of technology, which are not considered in the process of technical training of the student, in particular in the latest developments in the food industry;

- the proposed special course is the foundation for the study of methodical disciplines;

- after completing the special course, students undertake teaching practicum during which he/she applies knowledge and skills directly at handicraft lessons in school.

Having a general character, the special course "Fundamentals of modern technology" combines knowledge and skills from other technical disciplines based on the learned technical concepts, knowledge and skills. As opposed to the studied technical disciplines, the above course "Fundamen- 
Table 1

The system of disciplines for the training of future handicraft teachers to study the fundamentals of technology with students

\begin{tabular}{|c|c|c|c|}
\hline Year & Student activity & $\begin{array}{l}\text { Disciplines providing technical } \\
\text { training of the student }\end{array}$ & $\begin{array}{c}\text { Disciplines } \\
\text { providing } \\
\text { methodical } \\
\text { training of the } \\
\text { student } \\
\end{array}$ \\
\hline \multirow{11}{*}{1 year } & \multirow{18}{*}{$\begin{array}{l}\text { Acquisition of } \\
\text { general theoretical } \\
\text { knowledge, } \\
\text { practicing of simple } \\
\text { technical skills }\end{array}$} & Advanced mathematics & \multirow{5}{*}{$\begin{array}{l}\text { Introduction to } \\
\text { the specialty }\end{array}$} \\
\hline & & General physics & \\
\hline & & Descriptive geometry & \\
\hline & & Projection drawing & \\
\hline & & Construction materials engineering & \\
\hline & & $\begin{array}{l}\text { Standardization fundamentals and } \\
\text { quality management }\end{array}$ & \multirow{6}{*}{$\begin{array}{l}\text { General } \\
\text { psychology }\end{array}$} \\
\hline & & Garment industry equipment & \\
\hline & & Technology of garment manufacture & \\
\hline & & Textile materials technology & \\
\hline & & Technology of garment manufacture & \\
\hline & & Sewing training & \\
\hline \multirow{7}{*}{2 year } & & Philosophy (philosophy of technology) & \multirow{2}{*}{$\begin{array}{l}\text { Developmental } \\
\text { and } \\
\text { educational } \\
\text { psychology }\end{array}$} \\
\hline & & Machine drawing & \\
\hline & & Constructional drawing & \multirow{3}{*}{$\begin{array}{l}\text { Social } \\
\text { psychology }\end{array}$} \\
\hline & & Theoretical mechanics & \\
\hline & & Strength of materials & \\
\hline & & $\begin{array}{l}\text { Hydromechanics and hydraulic } \\
\text { machines }\end{array}$ & \multirow[t]{2}{*}{ Pedagogy } \\
\hline & & Sewing training & \\
\hline \multirow{8}{*}{3 year } & \multirow{8}{*}{$\begin{array}{l}\text { Formation of } \\
\text { more complex } \\
\text { set of scientific- } \\
\text { technical and other } \\
\text { knowledge, which } \\
\text { is a basis for more } \\
\text { complex skills }\end{array}$} & History of engineering and work & \multirow{3}{*}{ Art of teaching } \\
\hline & & Constructional drawing & \\
\hline & & Theory of machines and Mechanisms & \\
\hline & & Heat engineering and heat machines & \multirow{2}{*}{$\begin{array}{l}\text { Theory of } \\
\text { design and } \\
\text { technology } \\
\end{array}$} \\
\hline & & Machine elements & \\
\hline & & Metal cutting, plants and tools & \multirow{3}{*}{$\begin{array}{l}\text { Methodology } \\
\text { of design and } \\
\text { technology }\end{array}$} \\
\hline & & Basics of electronics & \\
\hline & & Practical training of electrical work & \\
\hline
\end{tabular}




\begin{tabular}{|c|c|c|c|}
\hline \multicolumn{4}{|r|}{ End of Table 1} \\
\hline Year & Student activity & $\begin{array}{l}\text { Disciplines providing technical } \\
\text { training of the student }\end{array}$ & $\begin{array}{c}\text { Disciplines } \\
\text { providing } \\
\text { methodical } \\
\text { training of the } \\
\text { student } \\
\end{array}$ \\
\hline \multirow{9}{*}{4 year } & \multirow{9}{*}{$\begin{array}{l}\text { Origin of technical } \\
\text { competence } \\
\text { and knowledge } \\
\text { functioning in } \\
\text { technical terms }\end{array}$} & Basics of occupational safety & \multirow{4}{*}{$\begin{array}{l}\text { Technology in } \\
\text { education }\end{array}$} \\
\hline & & Basics of environmental studies & \\
\hline & & Health and safety & \\
\hline & & Basics of electronics & \\
\hline & & $\begin{array}{l}\text { Maintenance and operation of } \\
\text { electronic and office equipment }\end{array}$ & \multirow{5}{*}{$\begin{array}{l}\text { Methodology } \\
\text { of specialized } \\
\text { of design and } \\
\text { technology }\end{array}$} \\
\hline & & Food processing equipment & \\
\hline & & $\begin{array}{l}\text { Basics of food processes of design and } \\
\text { technology }\end{array}$ & \\
\hline & & Cooking training & \\
\hline & & Fundamentals of modern technology & \\
\hline
\end{tabular}

tals of modern technology" envisages the studying of technology in general terms taking into account special aspects of the use of specialized equipment for garment and food industries.

\section{Analysis of academic disciplines for professional technical training}

To define the subject matter of the special course "Fundamentals of modern technology", it is necessary to solve the following tasks:

- to determine the essence of technical activities related to the special-purpose machines of garment and food industries;

- to formulate criteria for the selection of training toolkit that forms the fundamental for the study of the special course;

- to develop the content of the special course according to certain requirements.

Studying the concept "technology" that is a generalized name for various devices, mechanisms and equipment which were not available in nature but created by man to provide processes of production and maintenance of non-productive needs of society, the author determines that there is no its clear classification. Technology is conventionally divided into the areas of use: production, household, transport, calculation and others. Additionally, 
technology can be divided into production (engineering tools, instruments, measuring instruments) and non-production (household, passenger transport and recreation equipment) [5].

The activity of a handicraft teacher dealing with service-related work is connected with the study of technology of food and garment industry, thus it is expedient to consider production (garment and food production) and non-production (domestic cooking and sewing equipment) when choosing the content of training material.

When adopting the content of the special course "Fundamentals of modern technology", it is essential to define its tasks [15]:

- to generalize training material with further adoption of previously acquired knowledge, skills and expertise to new situations to reproduce all the features of special-purpose equipment, to exclude duplication of the content;

- to pay more attention to practical training and to increase students' independence;

- to set training hours for the development of professionally important personal qualities of a multi-skilled expert;

- to choose such types of technology which would reflect all the features of the object under consideration;

- to improve the quality and education competitiveness of a graduate.

As V. Kraievskyi and M. Skatkin mark, it is necessary to take into account the current deficiencies of the industry and to prevent them directly when forming the content $[14$, p. 6].

To take into consideration existing deficiencies in the available programs, it is essential to determine what curricula are bases for the development of the proposed special course and to analyze them. As the studying of "Fundamentals of modern technology" envisages the systematization, generalization and combination of knowledge of the courses "Technology of garment production" and "Technology of food industry", it is expedient to examine the curricula of the above courses to specify key issues for their further consideration when studying the proposed special course and to define the range of subjects not covered by the disciplines, but the study of which is necessary to ensure the modern technical training of the future handicraft teacher.

The course "Technology of garment industry" was developed from a standard program of higher pedagogical education institutions for master- 
ing the equipment of the garment industry under the editorship of $\mathrm{N}$. Bondar, Associate Professor, PhD in Pedagogy [2].

Please note that the course was developed from a standard program, thus it is not different from similar courses in other higher education institutions. Following the course, students become familiar with the classification of machine stitches, characteristics of lockstitch sewing machine, chain weave machines, semiautomatic machines, equipment of wet-heat processing, conveyance technologies of garment manufactures, equipment of preparatory-cutting shop and work rules for sewing machines.

The similar program "Fundamentals of Technology and Manual Training" was developed by S. Yashchuk [17]. During the course, students consider as follows: history, classification of technology, types of advanced technological processes, their impact on the universal space and importance for Ukraine, strategy for the future technological development of Ukraine, scientific and technological progress and intensification of production. Students learn the common patterns of development and operation of modern technology without focusing on the special aspects of sewing and cooking equipment.

The following program "Technology of Garment Manufacture" [9] includes the study of history, classification of garment enterprises, shuttle stitch, classification of machine needles, characteristics of universal machinery, faulty operation, maintenance support, equipment for wet-heat processing, single- and two-needle machines of shuttle stitch and chain stitch, overlock and thread-stitching machines, equipment of sewing enterprises.

None of the programs considers labour saving tools (sewing machine accessories) which have become quite necessary for household use, automated and computerized sewing equipment which has now become widespread, light repair of sewing equipment which students could do independently relying on technical knowledge and skills in the course "Repair and Operation of Electric Tools, Electrical and Office Equipment".

The program "Technological Equipment of Food Industry" was developed under the editorship of O. Plutok, Associate Professor, PhD in Pedagogy [8]. The discipline is studied during one academic semester: 12 hours take lecture material, 12 hours - laboratory-based work of students. When studying the discipline, students deal with the basic concepts of machines and mechanisms and mechanical equipment of food industry, machines for processing vegetables and potatoes, machines for processing fish and meat, 
machines for cooking creams and dough, thermal equipment, cooking and cooking-frying equipment.

The program "Production Equipment of Food Industry" [10] deals with the following cookery issues: classification of equipment of food industry, machines for processing vegetables, meat, fish, machines for preparation of confectionery raw materials, slicing bread, gastronomic goods, washing dishes, equipment for thermal processing, cooking equipment, grilling and baking equipment, universal heat apparatus (stoves), water heating equipment, auxiliary equipment, refrigeration equipment.

Studying the above programs, the author concludes that food-related equipment under consideration refers to the industry, and the attention is not paid to household and educational equipment which is directly used in the school during the lessons, and topics related to the study of modern developments in culinary are not covered.

Completion of the mentioned courses doesn't provide a student with the necessary scope of technical knowledge and skills sufficiently because, as a result of the training, students can't use technical knowledge in practice to the full extent and combine and acquire knowledge and skills in technical disciplines independently (the fact was established due to students' survey which was aimed at testing motivation level of students for learning technical disciplines: low level $-17.2 \%$, medium level $-28.6 \%$, sufficient level $-36.3 \%$ and high level $-17.9 \%$ ) that caused the reluctance to study and advance in knowledge independently among the majority of students.

The proposed special course "Fundamentals of modern technology" provides a combination of technical content "difficult" for the perception of future handicraft teachers with the practical implementation of the acquired knowledge, which is a prerequisite for increasing students' interest in learning the discipline.

Initially, students' knowledge and skills are quite different, so the above special course aims to summarize technical knowledge and skills. Such organization of training provides the following conditions for qualitative education of students for technical activity - a complication of academic material using common elements of knowledge and formation of holistic thinking of students based on theoretical interdisciplinary generalizations. 


\section{Content of the special course "Fundamentals of modern technology"}

To define the content of the special course following psychological-pedagogical peculiarities of a student's activity, effective organisation of study structure, interdisciplinary relationships, which are a foundation for technical training of the student, principles of selection of materials for students of technology faculties for their technical activities $[1 ; 6 ; 11 ; 13]$ and taking account specifics of the training of future handicraft teachers [7], the special course "Fundamentals of modern technology" is developed in terms of the principles of the study of modern technology:

1. The need to study several technical disciplines, multiple-option implementation of technical activities.

2. To include the basics of all sciences into the training content.

3. To use interdisciplinary relationships actively.

4. The content of the course should correspond to the modern development of science and technology.

5. To take into account the general level of students' knowledge when deciding on course content, that is, to structure training material in a logical and consistent development of basic knowledge when learning new information.

6. The content of the training material should reflect the principals of the object under study accurately.

7. The practical aspect of training should be principal in the content of academic disciplines.

8. Training material dealing with history of engineering should cover the essence, prospects for the development and ways of technology use in the world and Ukraine.

9. To form the environmental culture of a student using technology in the process of training.

10. The importance of presenting the relations of the elements of the object under study, their arrangement a clear form.

11. Organization of joint purposeful activity of lecturers and students, which is aimed at solving educational tasks.

12. Identification and cultivation of motives for the study of disciplines.

13. When selecting a training material, it should be ensured that its learning was completed with clear generalizations and conclusions. 
The special course "Fundamentals of modern technology" consists of two modules: the first is devoted to the acquaintance with the modern sewing equipment, and the second - to culinary equipment. Excursions to the enterprises of the garment and food industry are the competition of the study of each module that makes it possible to consolidate theory in practice more effectively.

A quite large number of exclusively technical disciplines, which have more propaedeutic nature for the training of a handicraft teacher dealing with service types of work, and a relatively small percentage of subjects aimed at direct familiarization of students with the types of technology that form the basis of the professional activity of the teacher (sewing and culinary equipment), unbalance the training of students. The knowledge and skills, which students acquire in the process of studying such disciplines, are inadequate to form the readiness of the future handicraft teacher to study the fundamentals of technology $[1 ; 4]$.

The abovementioned disciplines involve "History of technology development and handicraft", "Equipment of garment manufacture", "Equipment of food industry". Thus, the implementation of technical activities takes place at the lessons on machinery study, but that is not good enough to provide students with technical training. The proposed course "Fundamentals of modern technology" not only makes it possible to carry out technical activities during the practical part of the lessons but also to balance the technical training of future handicraft teachers to some extent as well as meets the first principle the need to study several technical disciplines.

The multiple-option implementation of technical training is that a technically competent teacher must not only have certain knowledge and skills: to have proficient knowledge of the structure and techniques of working with certain equipment, to adhere to the rules of equipment operation on stream, to comprehend the principle of action in such a way as to eliminate problems. Thus, it is expedient to hone technical knowledge and skills of accurate operation, regulation and repair of incorporated equipment in non-standard unconventional training situations.

The training content should involve the fundamental disciplines, and it is essential to rely on the knowledge of technical-oriented disciplines (advanced mathematics, general physics, descriptive geometry and drawing) and the use of other interdisciplinary relations when studying the 
special course. In developing academic content of the special course, the author uses the knowledge of fundamental disciplines: kinematic diagrams, sectional and cross-sectional views of equipment samples, application of elements of engineering when examining technology features, solution for technical problems, etc.

One of the guiding principles is to build the process of cognition in a logical sequence - from the easiest to the more complex. The proposed special course is organized in such a way that, first, it considers the simplest types of equipment and then - more sophisticated production equipment. The special course is full of complex theoretical material of technical focus, but its inclusion in the study process takes place at the third stage of the training when the complex of professional knowledge and skills of the student is formed at the sufficient level and available for senior students in the degree of complexity and abstraction. Thus, the author proposes to study the special course "Fundamentals of modern technology" at the 4th academic year relying on previous knowledge and skills. "Equipment of garment manufacture" and "Equipment of food industry" are disciplines which facilitate the consideration of the special course "Fundamentals of modern technology".

According to the special course "Fundamentals of modern technology", one of the training objectives is generalization and systematization of knowledge in specialized culinary and sewing equipment. Thus, the training is based on the key issues of garments and food industry, and taking into account of the requirements and content of the National Standard and school training program in a relevant subject is also important in the selection of course content.

Consequently, the basic equipment of the garment industry is a sewing machine, thus, it is expedient to include issues related to the operation on a sewing machine during the study of the special course, but it is advisable to consider sewing machines differently, taking into account the fact that students have some experience in working with such equipment.

An integral part of the process of manufacturing of sewn products is the use of machines of chain weaves in work - so-called overlocks. The modern garment industry uses machines of chain weaves of many types and modifications, and the choice of which influences the functions the equipment performs. Studying the peculiarities of equipment use allows organizing the manufacturing process of modern products as best as possible. 
As noted above, an important element for the training of handicraft teacher is the content density of the course or special course, taking into account the rapid development of world science and scientific nature of knowledge and skills. While working in the cookery classroom, the teacher uses a large amount of equipment that is part of the technological process of cooking: mixers, food processors, electric kettles, refrigerators, electric stoves etc. It is essential to have a relevant set of skills and expertise to work with specialized equipment. Analysing curriculum and academic programs, the author didn't find the issues devoted to the study of small and large cooking appliances.

With the development of science and the advancement of technology in the garment and food industries, equipment designed to facilitate or completely replace human work in performing certain operations or even in the process of manufacturing a particular object as a whole has become available. The operation of a sewing machine can be improved using special tools - labour-saving devices which grow in popularity among professional seamstresses. The sewing process is more productive if one knows their workability and ways for use.

Advanced garment machines have not yet been widely used in everyday life because of their high cost, but they have become an integral part of any garment enterprise. These are semi-automatic sewing machines, automated and computerized sewing equipment. The latest cooking appliances are more widely available for use in everyday life and are increasingly transformed from modern to everyday, e.g. the use of microwave ovens. Therefore, the handicraft teacher should be familiar with the global development trends in science and technology $[12 ; 16]$.

The use of a variety of wet and thermal equipment is an important component of garment production, thus the familiarization with the sewing technology is impossible without studying equipment.

One of the key principles - the training content should accurately reflect the principals of the object under study - to pass through the whole training material. Therefore, the topics of the special course are studied following a particular structure, taking into account all the peculiarities of the study of the technical object: the examination of the structure, principle of operation, functioning, classification, specifics of use, position in the technological process. 
An important principle of choosing the training content is the relevance of the theoretical material to its practical importance in order to approximate the training to practical reality to the maximum. Thus, during studying the special course "Fundamentals of modern technology", it is used a large number of samples of actual technology and its elements. The special course is replete with a large number of practical tasks of a creative nature, and challenging and technical tasks are solved at the lessons, etc. that influences the formation of expertise, development of skills and technical thinking much more effectively.

There is also a large number of equipment which is not used either in household use or in the process of training in the garments and food industries, but such machines are an inherent part of the industry with which a future handicraft training teacher should familiarize. Visual familiarization with the structure, operation principle of that sort of equipment is possible exclusively at manufacturing site, thus, the training program provides excursions to the garment and food enterprise. It also contributes to the consolidation of knowledge in practice along with a parallel study of the courses "Fundamentals of food technology" and "Cooking hands-on course".

The content of the special course also takes into account the principle of awareness of the assimilation and development of scientific thinking. For example, in studying history of the formation of modern garment and food technology, special attention is paid to the latest developments in the fields, prospects for their improvement, and the issues of development of science in Ukraine are considered. Therefore, the study of the special course starts with the topic "The content and objectives of the course. History of formation of modern garment and food technology".

It is clear that not only a particular bundle of theoretical knowledge and practical skills but also the general development of a person and his/her personality traits, which meet the requirements of the profession and education level, is an important component of modern training of a handicraft teacher. Much attention is paid to ecology through the world - the friendly coexistence of man and wildlife is an element of the general culture of any modern man.

First and foremost, environmental issues concern people who work with man-made objects, including technology. The future handicraft teacher should have environmental consciousness and accustom students to it. This is in line with the following principle of training organization, which requires the inclusion of environment-oriented content that explains the impact of 
technology development on nature and the tasks of a man relating to the issue. For this reason, the special course "Fundamentals of modern technology" provides issues concerning the environmental use of technology.

A necessary component for studying the fundamentals of the technology with students is the use of visualization, both in the form of natural objects and individual mechanisms as well as in the form of diagrams, posters, films of technical focus etc. Visualization goes along with classroom sessions when the teacher explains the structure, principles of action, mechanisms, etc. and laboratory classes when the student can get acquainted with the technical objects in more detail or particular mechanisms under consideration independently.

In studying the special course, the motivation of the students is prioritized: the lecturer forms a positive attitude of students to work with the use of modern technology, emphasizes the importance of practicing technical knowledge and thinking to ensure high-quality technical activities for students.

The practical part of the special course is full of various tasks due to which the student actively participates in the work.

The developed curriculum has been expertly evaluated by lecturers of specialized disciplines, experts in industrial training, handicraft teachers all experts have at least 10 years of experience and a large number of personal experience in this field, academic titles, relevant education and qualifications. Following the comments made by the experts and improvement of the program of the special course, the experts approved the final version of the program of the special course "Fundamentals of modern technology".

The program of the special course "Fundamentals of modern technology" provides students with the basic concepts of modern equipment used in the sewing and food industries (Table 2).

The training goal of the program is to develop the knowledge and skills of modern technology for future teachers to ensure the qualitative study of the basics of technology with the students at handicraft classes in school.

The special course "Fundamentals of modern technology" includes general theoretical and practical training for students necessary for:

- qualitative and competent study of technology with students in a general educational institution;

- technically competent operation of the equipment of workshops and classrooms of a general educational institution; 
- use of acquired knowledge and skills at hobby clubs.

The program of the special course is designed for 18 hours of lectures, 18 hours of practical training. The lecture content of the program consists of the following sections: garments technology, food technology. Laboratory activity provides independent work of students on all sections of the special course. In the process of studying the special course, students make up reports and give a report on laboratory-based work done. The program "Fundamentals of modern technology" consists of two modules.

After the completion of the special course "Fundamentals of modern technology", it is expedient to pay attention to the topics related to the use of technology while considering the courses "Methodology of industry-specific training" and "Methods of handicraft and professional training".

Table 2

Syllabus of the special course "Fundamentals of modern technology"

\begin{tabular}{|c|c|c|c|c|}
\hline \multirow[b]{2}{*}{ № } & \multirow[b]{2}{*}{ Topics } & \multicolumn{3}{|c|}{ Number of hours } \\
\hline & & Lectures & \begin{tabular}{|c|} 
Practical \\
training
\end{tabular} & Total \\
\hline \multicolumn{5}{|c|}{ Module 1. Garment technology } \\
\hline 1. & $\begin{array}{l}\text { Content and goals of the course. History of } \\
\text { formation of modern garment and food equipment }\end{array}$ & 2 & 2 & 4 \\
\hline 2. & Modern sewing machines & 2 & 2 & 4 \\
\hline 3. & Automated and computerized sewing technology & 2 & 2 & 4 \\
\hline 4. & Equipment of sewing enterprises & 2 & 2 & 4 \\
\hline 5. & Repair and operation of garment equipment & 2 & 2 & 4 \\
\hline \multicolumn{5}{|c|}{ Module 2. Food technology } \\
\hline 6. & Modern small cook appliances & 2 & 2 & 4 \\
\hline 7. & $\begin{array}{l}\text { Large cook appliances and equipment of food } \\
\text { enterprises }\end{array}$ & 2 & 2 & 4 \\
\hline 8. & Cutting edge cooking technologies & 2 & 2 & 4 \\
\hline 9. & Repair and operation of garment equipment & 2 & 2 & 4 \\
\hline & Total: & 18 & 18 & 36 \\
\hline
\end{tabular}

Thus, based on knowledge and skills gained by students in the context of the special course "Fundamentals of modern technology", methodological courses and developed methodological recommendations, it is essential to conduct teaching practice by stages: 
- at the first stage, to conduct handicraft lessons at the classes assigned to student-trainee using methodological recommendations;

- at the second stage, to monitor the students in order to control their efficiency;

- at the third stage - at the end of teaching practice - each student should conduct a general analysis of work [11, p. 38-39].

During the teaching practice, students should also pay attention to:

- the provision of lessons with high-quality visualization because in such context, it is easier for girls to perceive complex technical information;

- the use of both traditional and innovative teaching methods;

- the importance of carrying out elective course or attending classes of other teachers;

- the implementation of self-analysis of the work by trainees.

Upon the completion of teaching practice, it is expedient, besides the reports of students, to communicate with teachers, methodological experts, to conduct questionnaires on the expediency and quality of the developed methodological recommendations.

Thus, for the professional training of future handicraft teachers to study the fundamentals of technology with students, it is necessary to use the following components of qualitative assurance of students' readiness for technical activity with students: introduction of in-depth and integration and integrated special course "Fundamentals of modern technology" into the curriculum, practicing gained technical skills during the methodological training of the student at the classes and their consolidation during the teaching practice.

\section{Conclusions}

Considering the problems of readiness of future teachers to study the fundamentals of technology with students, the analysis of training of students of technology faculties was conducted. The purpose of the research is to identify the academic courses that provided technical training for a student of a higher pedagogical education institution. In the context of the analysis of the defined courses, the key issues relevant to the study by the students of technical faculties are defined. The stages of implementation of modern technical training of future handicraft teachers are studied, and the interdisciplinary relations are established. 
Based on scholarly opinions, the author determines that one of the crucial shortcomings in education is the gap of theoretical developments in the scientific field to the practical use of modern man-made objects in the educational process of higher education institutions. The solution to the drawback is the creation of integrated technical courses where the use of interdisciplinary relationships is a key element for their formation.

The author proposes the special course "Fundamentals of modern technology" following the requirements of technology curriculum, principles of selection of the content of technical training of future teachers and taking into account current trends in the development of garment and food industries. The position of the special course in students' curriculum and the main components of the special course "Fundamentals of modern technology" are defined: the study of theoretical material, practical use of knowledge for the formation of technical skills, diagnostics of the quality of assimilating knowledge and skills.

Based on the principles of choice of content and peculiarities of formation of technical training of future handicraft teachers, it is developed a program and special course "Fundamentals of modern technology" with the purpose of systematization, generalization and extension of technical knowledge, skills and development of technical thinking.

To ensure the effectiveness of the introduction of the special course, the paper develops the methodology for its implementation using problem-based learning, solving technical tasks and problems, working with modern garment and cooking technology, students' independent work.

\section{Referenses:}

1. Bohdanov R.I. (2012). Doslidnytska kompetentnist maibutnikh inzhenerivpedahohiv [Research competence of future engineers-educators]. Zbirnyknaukovykh prats Berdianskoho derzhavnoho pedahohichnoho universytetu, 2, 43-48.

2. Bondar N.O. (2017). Prohrama «Obladnannia shveinoho vyrobnytstva»: dlia studentiv tekhnolohichnykh fakultetiv pedahohichnykh navchalnykh zakladiv [The program «Equipment for sewing production»: for students of technological faculties of pedagogical educational institutions]. Chernihiv: ChNPU.

3. Vasil'ev Yu.K. (1978). Politexnicheskaya podgotovka uchitelya srednej shkoly [Polytechnic training of a secondary school teacher]. Moskva: Pedagogika.

4. Vernadskij V.I. (1975). Razmyshleniya naturalista: v 2-x kn. Kn. 1. Prostranstvo i vremya v nezhivoj i zhivoj prirode [Reflections of a naturalist: in 2 books. Prince 1. Space and time in inanimate and living nature]. Moskva: Nauka. 
5. Hushulei Y.M. (1996). Osnovy tekhniky: Navch.posibnyk dlia 8-9 kl., sered. zahalnoosvi. shk. [Fundamentals of Engineering]. Kyiv: Osvita.

6. Kurok V. (2004). Kontseptsiia inzhenernoi pidhotovky maibutnikh uchyteliv trudovoho navchannia [The concept of engineering training for future teachers of vocational training]. Vyshcha osvita Ukrainy, 3, 73-79.

7. Navchalna prohrama $\mathrm{z}$ trudovoho navchannia dlia zakladiv zahalnoi serednoi osvity 5-9 klasy [Vocational training program for general secondary education institutions grades 5-9].URL:https://mon.gov.ua/ua/osvita/zagalna-serednya-osvita/ navchalni-programi/navchalni-programi

8. Plutok O.V. (2018). Prohrama «Tekhnolohichne obladnannia kharchovoi promyslovosti» dlia studentiv tekhnolohichnykh fakultetiv pedahohichnykh navchalnykh zakladiv [Program «Technological Equipment of Food Industry» for students of technological faculties of pedagogical educational institutions]. Chernihiv: ChNPU.

9. Prohrama «Obladnannia shveinoho vyrobnytstva» [The program «Equipment for sewing production»]. URL: http://ncpn.net.ua/shveyne-obladnannyal.html

10. Prohrama «Tekhnolohichne obladnannia kharchovoi haluzi» [Program «Food processing equipment»]. URL: http://www.uipa.kharkov.ua/files/pdf/OP/ Tehn/pisheviki/TOHG.pdf

11. Radzikhovska L.M. (2009). Pedahohichni umovy formuvannia hotovnosti maibutnikh uchyteliv matematyky do roboty z obdarovanymy ditmy: dys. kand.. ped. nauk: 13.00.04 [Pedagogical conditions for forming the readiness of future mathematics teachers to work with gifted children: Diss. Cand. Sciences: 13.00.04]. Chernihiv.

12. Sydorenko V. (2010). Vplyv sotsialno-ekonomichnykh protsesiv u suspilstvi na vyznachennia pidkhodiv do trudovoho navchannia shkoliariv [Influence of socioeconomic processes in society on the definition of approaches to work training of students]. Trudova pidhotovka v zakladakh osvity, 7-8, 3-7.

13. Sydorenko V. (2005). Politekhnichna osvita: suchasne bachennia problemy [Polytechnic education: a modern vision of the problem]. Trudova pidhotovka $v$ zakladakh osvity, 2, 4-7.

14. Skatkin M.M. (1981). Soderzhanie obshhego srednego obrazovaniya: Problemy i perspektivy [The content of secondary education: Problems and prospects]. Moskva: Znanie.

15. Stakhmych T. (2010). Pidhotovka kvalifikovanykh robitnykiv na osnovi intehratyvnoi orhanizatsii navchalnoho protsesu [Training of skilled workers on the basis of integrative organization of educational process]. Zbirnyk naukovykh prats Umanskoho derzhavnoho pedahohichnoho universytetu imeni Pavla Tychyny, 3, 206-214.

16. Khovrych M.O. (1996). Vyznachennia profesiinoi hotovnosti studentiv do roboty vchytelia pratsi. Psykholoho-pedahohichni problemy pidhotovky vchyteliv [Determination of students' professional readiness for work as a teacher of work]. Materialy yuvileinoi naukovoi konferentsii, prysviachenoi 80-richchiu Chernihivskoho derzhavnoho pedahohichnoho instytutu im. T.H. Shevchenka, 2, 22-24.

17. Yashchuk S.M. Osnovy tekhniky ta tekhnolohii [Fundamentals of engineering and technology]. URL: http://tpf.udpu.org.ua/inf_paket3/jkj\%20(22).pdf 